\title{
E-Wallet Application Penetration for Financial Inclusion in Indonesia
}

\author{
Augi Ciptarianto ${ }^{1}$, Yudo Anggoro ${ }^{2}$ \\ ${ }^{1,2}$ School of Business and Management, Institut Teknologi Bandung
}

\begin{abstract}
Indonesia is an archipelago country with more than 270 million inhabitants spread across urban and rural regions. This makes digital payment penetration a challenge in itself. Private and government e-wallet service providers have sought to increase the use of cashless services to address structural deficiencies in the country's economy, such as poor financial inclusion and heavy reliance on manual remittances. This study discusses penetration problems that occur in the e-wallet industry and formulates the strategy so that the use of digital payment platforms can be carried out evenly in all regions of Indonesia. This study notes that technology enablement such as smartphone and internet penetration does not correlate with e-wallet penetration. Many underlying factors affect the penetration, such as key driving forces, infrastructure readiness, and people's perception of the safety and security of mobile transactions. Bank Indonesia and e-wallet providers are responsible to educate people about the advantages along with possible risks of adopting e-wallet as a non-cash payment method.
\end{abstract}

KEYWORDS: Digital Payment, Indonesia, Financial Inclusion, Penetration.

\section{INTRODUCTION}

Indonesia is the fourth most populated country in the world, dominated by young people with an average age of 31 years old. In addition, McKinsey \& Company predicts that by 2030, Indonesia will become the seventh-largest economy, with more than 60 percent of the productive age entering middle-class status, as well as the consumer class predicted to increase from 45 million in 2010 to 140 million in 2030 (Oberman et al. 2012). Indonesia also has a very significant growth in internet and smartphone users, ensuring Indonesia's position as one of the countries with the largest digital base in the world.

Despite having a lot of economic potentials, Indonesia faces many challenges, one of which is financial inclusion as a supporting factor for economic growth. Compared to other Southeast Asian countries, Indonesia still relies a lot on manual remittances. As an archipelago country, Indonesia has unequal access to banking, creating unequal access to finance both in urban and rural areas.

Financial technology, or fintech, plays a critical role in making a seamless payment system. Electronic money payments and ewallet are the most popular forms of fintech services in Indonesia, followed by web-based investments and pay later services. As of February 2020, 41 licensed e-wallet providers have been approved by Indonesian government regulators. The top 5 e-wallet providers in Indonesia based on the number of monthly active users are GoPay, OVO, Dana, LinkAja, and ShopeePay. Considering its market value, support from investors, and solid partnerships with large banks, the e-wallet application has a massive potential to penetrate more widely across Indonesia.

\section{E-Wallet Application in Indonesia}

Indonesian consumers are very receptive to the new products in this digital economy. The market growth of fintech products in Indonesia shows an upward trend, proven by the increase of both the transaction value and the number of startups. Bank Indonesia (BI) shows that the value of electronic money transactions has reached IDR 201 trillion ( $\$ 13.95$ billion) in 2020, growing by 38.62 percent from IDR 145 trillion ( $\$ 10.07$ billion) in 2019. As of January 2020, the largest driver of digital transactions is retail at 28 percent, followed by transportation ( 27 percent), food order (20 percent), e-commerce (15 percent), and bill payments ( 7 percent).

However, Indonesia is still often referred to as an "underbanked" country with more than 50 percent unbanked (Bank Indonesia, 2020). But nowadays it is rapidly changing as e-wallet bring more financial and security options to the country. The top e-wallet providers offer a lot of conveniences, but more than that, they have integrated with other companies to provide additional services to customers. For example, several fintech startups have collaborated with ride-hailing services, food delivery applications, and entertainment services to make seamless transactions. These startups are still vying for their position in an ever-expanding economy, 


\section{International Journal of Current Science Research and Review}

ISSN: 2581-8341

Volume 05 Issue 02 February 2022

DOI: 10.47191/ijcsrr/V5-i2-03, Impact Factor: 5.825

IJCSRR@ 2022

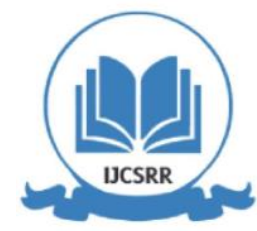

www.ijjesrr.org

but they have made it this far. As technology develops, and society becomes more receptive to internet banking services, Indonesian startups seem favorable to gain success soon.

The increase in digital payment transactions reflects the development of the digital financial literacy of the Indonesian population. This also shows the increasing acceptance of fintech and e-commerce services in the country. BI estimates that the absorption of digital transactions will continue with the growth of e-commerce and electronic payments.

\section{Problem Statement}

The Indonesian Internet Service Provider Association (APJII) survey from 2019 to the second quarter of 2020, the number of internet users in Indonesia reached 196.7 million, or 73.7 percent of the total population. In comparison to the prior number of users, the penetration rate increased by 8.9 percent. Even so, the growth rate for $2019-$ Q2 2020 is still lower than the growth rate in 2018 which reached 10.12 percent.

Further, the penetration of smartphone users in Indonesia is also relatively high. Newzoo's Global Mobile Market Report 2020 revealed that Indonesia's population with a smartphone reached 160.23 million, 58.6 percent of the total population. This number will continue to rise as infrastructure improves, monthly data plans become more affordable, higher education expands, and local content develops.

With the high percentage of internet users and smartphone penetration. However, the use of an e-wallet as a transaction method is still relatively low. Based on Boku Inc.'s Mobile Wallets Report 2021, Indonesia's total number of e-wallet users is recorded at 63.6 million, only 25.6 percent of the total population, and it is predicted to reach 202 million users by 2025 .

With the country's growing internet and online transactions, e-wallet providers face tough challenges to penetrate the country. Azali (2016) described the challenges of digital payment adoption in Indonesia as follows.

1. Culture and language barriers, diverse set of languages and cultures with more than 300 ethnic groups spread over an archipelago of 17.508 islands.

2. Reliance towards cash payments, with limited use of e-wallet as a transaction method.

3. Decentralized distribution networks, the 41 licensed e-wallet providers have different operators, users, and potential markets. Challenge in enforcing centralized laws and regulations amidst ever-shifting market forces.

4. Decentralized government authority, power has been distributed from the center to hundreds of sub-national areas, resulting in a highly fragmented economy with significant interoperability and e-wallet acceptance issues.

5. Spotty internet coverage, with internet speed rated as lowest in Southeast Asia. This will be extremely difficult to create a long-term infrastructure for connectivity.

The subjects and analysis of this study are for five prominent e-wallet providers in Indonesia: OVO, ShopeePay, LinkAja, GoPay, and Dana. Using secondary data and surveys, the study will help these e-wallet providers understand customer behavior, along with an untapped market standpoint to define their motivation as a baseline for product promotion or offerings, and formulate strategies to increase penetration of their products in the country.

\section{Research Objectives}

This study will help five e-wallet providers be aware of the key challenges in the existing business climate in Indonesia. The study will also showcase the customer behavior towards e-wallet products, as well as reasons and motivation to use e-wallet through a primary survey to people who currently don't have an e-wallet account. Insights from both existing users and non-users can be a baseline for the e-wallet providers to create a product or promotion that fits their needs, as well as understanding people's expectations towards e-wallet product offerings.

The strategy formulation and recommendations will help five e-wallet providers penetrate and increase the adoption of e-wallet across Indonesia. Further, the given solutions and recommendations will help stakeholders such as policymakers and supporting stakeholders to synergize in increasing the adoption of e-wallet in the country. 


\section{International Journal of Current Science Research and Review}

ISSN: 2581-8341

Volume 05 Issue 02 February 2022

DOI: 10.47191/ijcsrr/V5-i2-03, Impact Factor: 5.825

IJCSRR@ 2022

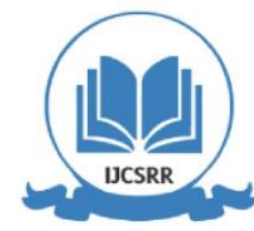

www.ijcsrr.org

\section{Methods}

There are two ways to obtain the primary data in this study. First, in-depth interviews with e-wallet players, specifically with representatives from e-wallet companies under this study. Second, surveys with people who never use e-wallet as a payment method and currently don't have any e-wallet accounts. The survey specifically targets people who live in urban and rural areas in Indonesia, categorized as productive ages ranging from 15 to 64 years old. The information obtained is the answer from the results of filling out the questionnaire by the respondents.

The primary study aims to validate challenges of digital payment adoption in Indonesia provided by Azali (2016), then use descriptive data to support the analysis. The survey sampling was carried out using a non-probability sampling procedure with a purposive sampling method using certain criteria to obtain the necessary information.

The number of samples for the survey was determined using the Slovin formula:

$$
n=\frac{N}{1+N e^{2}}
$$

Where $\mathrm{N}$ is the total population of non-e-wallet users within the working age, and e is the error tolerance.

According to the World Bank, the total of Indonesia's productive age in 2020 is 185.453 .064 people. There is approximately 22 percent of e-wallet transactions on e-commerce in 2020, then we can get 78 percent non-e-wallet transactions. With several adjustments, there is a roughly 144,653,390 target population. Using the Slovin formula, the sample can be calculated as follows.

$$
n=\frac{144,653,000}{1+144,653,390 * 0.05^{2}}
$$

Therefore, this study requires $\sim 399.9$ samples or rounded to 400 with a confidence level of 95 percent.

The questionnaires are spread through various channels, such as email broadcast, social media, direct message through messaging platforms, and direct approach to the target participants. Out of 400 target participants, there are 137 responses in total, but after conducting a data cleansing, there are only 111 participants who currently don't have any e-wallet account. The response rate was 34.25 percent, with 27.75 percent as valid data.

To further support and validate the primary findings, secondary data are needed. By leveraging initial market study to understand the digital payment landscape in Indonesia, then observe user behavior towards e-wallet and e-wallet usage comparison in Indonesia. Each e-wallet provider offers different services and benefits for their users, this will help understand the gap between untapped market expectations and existing product offerings that e-wallet providers have.

\section{Hypothesis}

Based on Azali's (2016) findings of digital payment adoption challenges in Indonesia, there are five hypotheses to be proven in this study.

Table 1. Research hypothesis

\begin{tabular}{|l|l|l|}
\hline Stakeholders & Problem & Hypothesis \\
\hline E-Wallet providers & $\begin{array}{l}\text { Culture and language } \\
\text { barriers }\end{array}$ & $\begin{array}{l}\text { There is a massive knowledge gap due to } \\
\text { disparity in access to e-wallet information. }\end{array}$ \\
\cline { 2 - 3 } & Reliance on cash payments & $\begin{array}{l}\text { People still find cash transactions as the } \\
\text { easiest transaction method; hence they don't } \\
\text { see the benefit of using the e-wallet. }\end{array}$ \\
\cline { 2 - 3 } & $\begin{array}{l}\text { Decentralized distribution } \\
\text { networks }\end{array}$ & $\begin{array}{l}\text { Different operators, users, and potential } \\
\text { markets among e-wallet providers create } \\
\text { challenges in enforcing centralized laws and } \\
\text { regulations. }\end{array}$ \\
\hline
\end{tabular}




\section{International Journal of Current Science Research and Review}

ISSN: 2581-8341

Volume 05 Issue 02 February 2022

DOI: 10.47191/ijesrr/V5-i2-03, Impact Factor: 5.825

IJCSRR@ 2022

Www.ijcsrr.org

\begin{tabular}{|l|l|l|}
\hline $\begin{array}{l}\text { Government or } \\
\text { policymakers }\end{array}$ & $\begin{array}{l}\text { Decentralized government } \\
\text { authority }\end{array}$ & $\begin{array}{l}\text { Dispersed government authority causes a } \\
\text { highly fragmented market. }\end{array}$ \\
\cline { 2 - 3 } & Spotty internet coverage & $\begin{array}{l}\text { Weak internet connection hinders the long- } \\
\text { term infrastructure development for } \\
\text { connectivity. }\end{array}$ \\
\hline
\end{tabular}

\section{LITERATURE REVIEW}

There are two stakeholders covered: e-wallet providers, and government or policymakers. These stakeholders have mutual benefits from one another. E-wallet providers provide a product that offers a seamless payment system for a nation's citizens, and the government regulates them. In a sense that these synergies must be able to empower each other, build trust and security for the people.

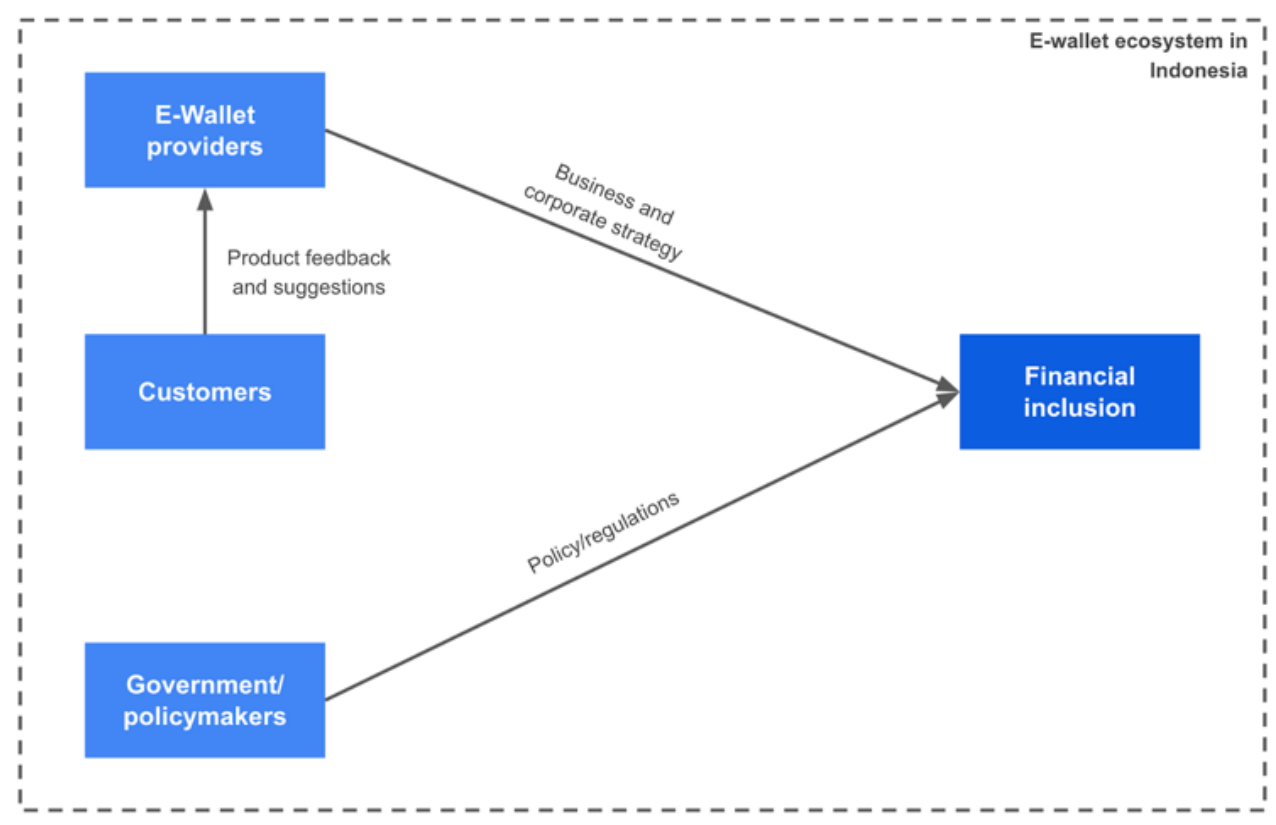

Figure 1. Conceptual framework of the study

Customer feedback is also included in this study to understand their behavior towards e-wallet products, where they use them, and their motivation to use the e-wallet. Further, the primary survey will discover the sample of people who currently don't have an ewallet account. These insights will help five e-wallet providers create e-wallet products and offerings that fit their needs, improve customer satisfaction, and expand new users by understanding their motivation and expectation towards the services.

\section{Financial Inclusion}

In general, financial inclusion efforts aim to reach out to the unbanked and provide them with sustainable financial services. Financial inclusion has been linked to better and more sustainable economic growth and development, and as a result, many governments throughout the world, including Indonesia, have made it a priority to achieve it.

Although it is acknowledged that not everyone requires or desires financial services, the goal of financial inclusion is to eliminate all barriers, both supply and demand. Supply-side barriers stem from financial institutions themselves. They frequently imply a lack of financial infrastructures, such as a lack of local financial institutions, expensive account opening charges, or verification requirements. Individuals seeking financial services face demand-side constraints such as low financial literacy, a lack of financial capability, or cultural or religious views that influence their financial decisions. 


\section{International Journal of Current Science Research and Review}

ISSN: 2581-8341

\section{Volume 05 Issue 02 February 2022}

DOI: 10.47191/ijcsrr/V5-i2-03, Impact Factor: 5.825

IJCSRR@ 2022

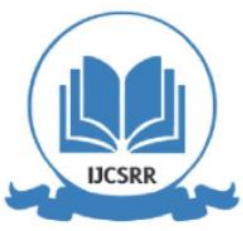

www.ijcsrr.org

\section{Government Plans to Promote Cashless Transactions}

Planned reductions in cash transactions and increased financial inclusion have been hampered by several delays and roadblocks. In 2014, in collaboration with the Association of Payment Systems of Indonesia (ASPI), BI established the "National Non-Cash Movement (Gerakan Nasional Non-Tunai, GNNT)". The campaign's goal was to promote public awareness of the usage of noncash instruments and subsequently form a society comfortable with using non-cash instruments (the Less Cash Society). While GNNT has encouraged the use of non-cash transactions, there is no long-term plan or clear mechanism in place to grow noncash instruments.

In 2015, BI reaffirmed its decision to establish a master plan for an integrated payment system known as the National Payment Gateway (NPG), which would serve as the primary infrastructure for financial services and payments (Amianti, 2015). The plan would supervise electronic payment interoperability using a variety of instruments, including ATMs, debit and credit cards, and emoney.

\section{RESULTS AND DISCUSSION}

\section{Secondary Research}

The secondary research aims to understand Indonesia's internet and smartphone landscape. E-wallet adoption is heavily dependent on internet usage within a country, so a country must make sure the internet is used widely, by building a reliable telecommunication infrastructure that reaches remote areas across the country.

\section{Indonesia's Internet Landscape}

A survey from APJII (2020) revealed that Indonesia's internet penetration rate has gone up to 73.7 percent. This means that the country starts to catch up with neighboring countries such as the Philippines, Vietnam, and Thailand.

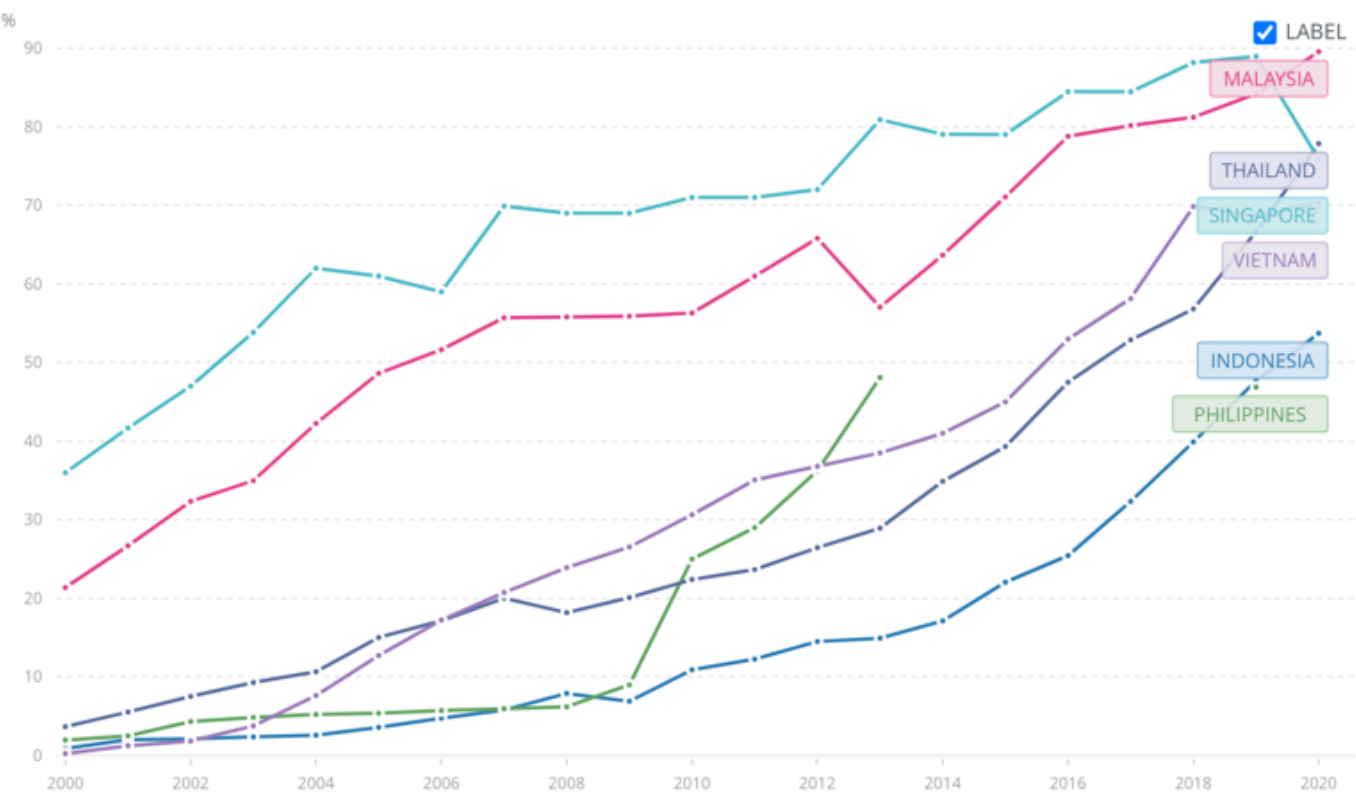

Figure 2. Internet users as a percentage of the population in selected Southeast Asian countries Source: Compiled from World Development Indicators, World Bank (2000-2020)

Despite having more internet users, the connectivity is still highly concentrated in Java, the country's most populous island. Then followed by Sumatra, Sulawesi, Kalimantan, Bali and Nusa Tenggara, and lastly, Maluku and Papua. Indonesia remains in 56th place in the digital competitive index due to uneven internet access. As the country remains struggling to provide reliable internet infrastructure in remote areas. 


\section{International Journal of Current Science Research and Review}

ISSN: 2581-8341

\section{Volume 05 Issue 02 February 2022}

DOI: 10.47191/ijcsrr/V5-i2-03, Impact Factor: 5.825

IJCSRR@ 2022

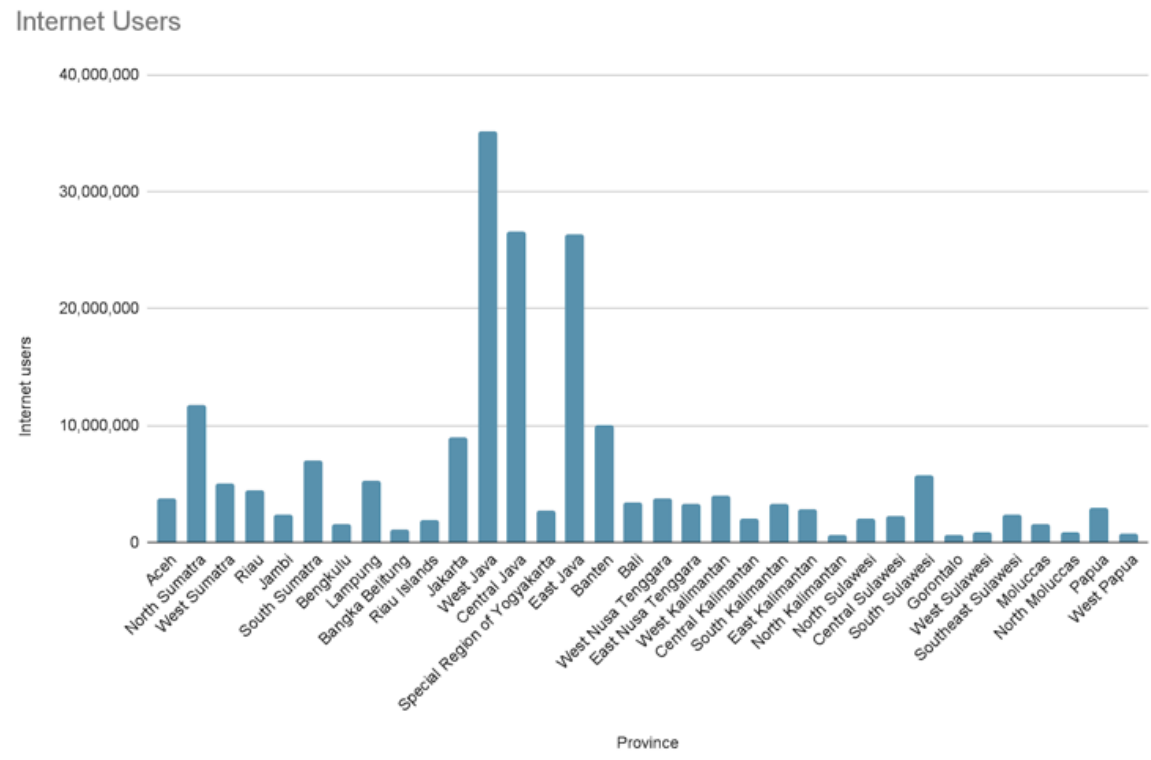

Figure 3. Number of internet users by region in Indonesia

Source: Indonesia Internet Service Provider Association (2019)

APJII also shows that up to 95 percent of Indonesians use smartphones connected with mobile data to access the internet, with fewer than 10 percent utilizing a fixed broadband connection at the home, office, or public spaces. This indicates that despite low internet penetration in certain areas, the effort to educate people to use e-wallet for mobile payment remains possible.

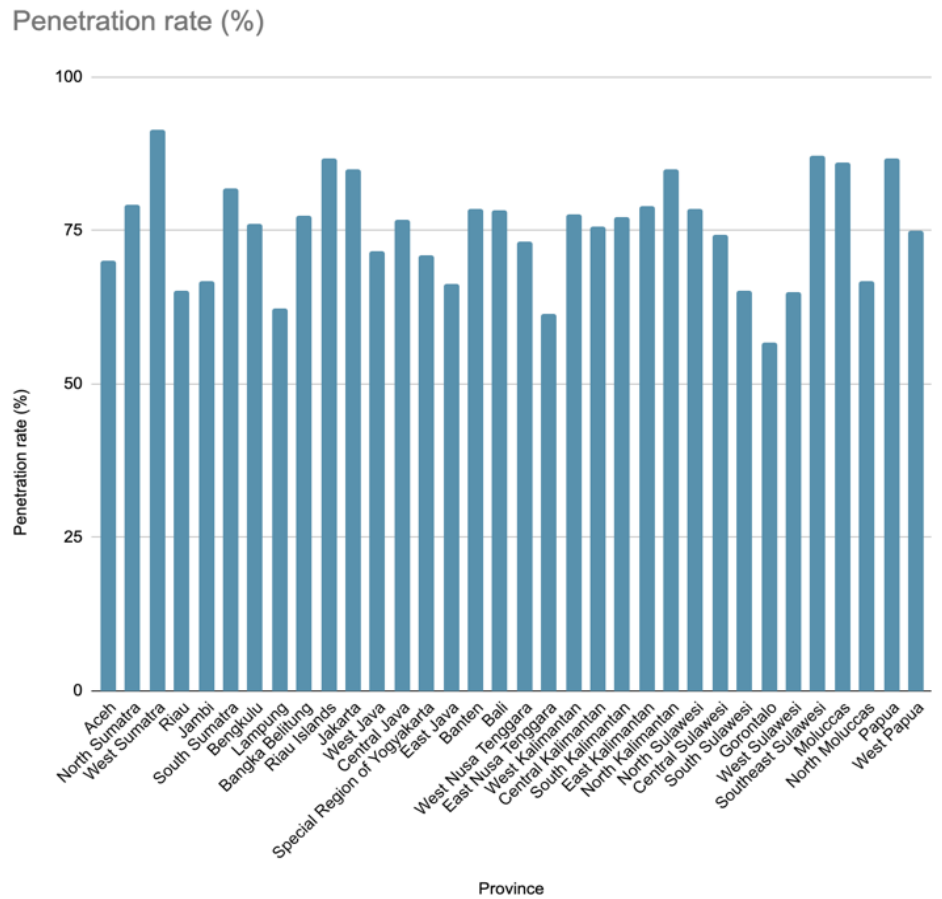

Figure 4. Internet penetration by region in Indonesia

Source: Indonesia Internet Service Provider Association (2019) 


\section{International Journal of Current Science Research and Review}

ISSN: 2581-8341

Volume 05 Issue 02 February 2022

DOI: 10.47191/ijcsrr/V5-i2-03, Impact Factor: 5.825

IJCSRR@ 2022

www.ijcsrr.org

\section{Factors Affecting Prospects for E-Wallet Use}

a. Customer Behavior

A study from Boku.Inc (2021) which sampled 1,035 respondents, found that customers in Indonesia use an average of 3.2 wallets in use per respondent. The study also found that cash is the payment option that is being displaced the most by the usage of e-wallets. The payment methods that have been replaced the most include bank transfers and debit cards. Even paying using mobile phone providers outperformed credit cards, which is likely due to Indonesia's low credit card penetration rate.

Like those in other emerging countries, Indonesian customers utilize mobile wallets for a variety of purposes. Customers are utilizing mobile wallets for $\mathrm{P} 2 \mathrm{P}$ transfers, bill payments, receiving payments, and withdrawing cash at high rates, even though payments and mobile top-ups are the top use cases. Meaning that the e-wallet is being used as a stand-in for a bank account.

Cashback and discounts are also mentioned as important drivers of e-wallet usage, and utilizing various wallets allows users to gain different benefits. This can occur either as a result of the wallets themselves giving various benefits or as a result of marketing that certain wallets may have with specific merchants.

\section{b. Infrastructure: Banking, Telephony, and Internet}

Indonesia's biggest pain points come under the infrastructure category, including factors such as broadband penetration, average mobile connection speed, and internet architecture (Freischlad, 2015). Individual pain points include a huge unbanked population, a high number of people not using online financing instruments, and a high level of adults unfamiliar with banking services. Information issues include the availability of content in the home language, press freedom, and filtering (Freedom House, 2020).

Indonesia's physical infrastructure is of poor quality and coverage, and it continues to be a major impediment to progress. Since the late 1990s, there has been a lack of investment in infrastructure, resulting in low quality and quantity of physical infrastructure. Following the Asian Financial Crisis in 1998, the government's development spending was drastically curtailed, and Indonesia's infrastructure spending was cut in half compared to the Soeharto period (Aswicahyono and Hill 2015). Infrastructure has improved gradually and slowly over the last decade, but it is still lagging far behind.

Landline use in Indonesia has always been low. Citizens have had to wait years for a phone connection to be extended into their neighborhoods, much less their homes since telephone lines have been controlled by governmental agencies. To put it another way, the telecommunications and internet industries in Indonesia are largely concerned with mobile transactions. The majority of internet users in Indonesia have switched from fixed to mobile connections. With the growing use of mobile phones, there are strong expectations that networks would be able to deliver and extend financial services to many Indonesia's unbanked people (IFC World Bank, 2010).

Three major operators dominate the mobile network communications industry: Telkomsel, Indosat, and XL Axiata, with a combined market share of roughly 85 percent. These companies have a huge impact on the internet and telecommunications sectors in Indonesia, which is constantly expanding. They also have a significant role in determining how standards, protocols, payment, and security systems are used and implemented. This implies that to go forward with non-cash payments like e-wallet, Indonesia should conceive of current networks as untapped resources.

c. Regulations, Standard, and Security

BI is responsible for maintaining the rupiah's stability, stated under Act No. 23 of 1999. It accomplishes this in part through regulating and managing the National Payment System (NPS). Individual bank supervision (micro-prudential) has been moved from the BI to the Financial Service Authority (OJK) as of December 31, 2013. The Association of Payment Systems in Indonesia (ASPI) and the Forum for Indonesian Payment System (FPSI) have both been formed.

Further, BI also determines the set of regulations governing NPS on the forms and quality of payment mechanisms. BI processes high-value non-cash payments using the BI-RTGS (Real Time Gross Settlement) system and the Clearing System, Indonesia's main conduit for financial transaction settlement. BI-RTGS is a Systemically Important Payment System (SIPS), which means it handles high-value and time-sensitive transactions. There are also SWIPS (System-Wide Important Payment Systems), which include the clearing system and public-use card-based instruments. 


\section{International Journal of Current Science Research and Review}

ISSN: 2581-8341

Volume 05 Issue 02 February 2022

DOI: 10.47191/ijcsrr/V5-i2-03, Impact Factor: 5.825

IJCSRR@ 2022

www.ijjcsrr.org

BI has reaffirmed its commitment to the long-delayed master plan for an integrated NPG, which has been delayed since 2012 (Amianti, 2015). The NPG aspires to create a single organization that will manage the interconnection of all electronic payments made with a variety of instruments, such as debit cards, credit cards, and electronic money. It would also be compatible with the BIRTGS.

The present trends in non-cash transactions appear to be highly influenced by the development of the mobile market, where major companies have a significant effect on the sector's development. The result hasn't been ideal. Mobile development is still reliant on existing infrastructure for signals, connectivity, and security, all of which are variable based on location. Delays and failures in transactions to and from their devices and banks are common (Boellstorff et al. 2013).

Moreover, fraudulent firms are widespread, such as those that advertise on social media and Google. They are difficult to identify, and even if possible, with long-standing poor law enforcement, there's nothing that can be done legally (Wirdana, 2014). It's not just a matter of trust in payment security; it's also a problem of trust in travel logistics and business. Hence, most online shoppers prefer paying through ATMs or the cash on delivery (COD) method to using the e-wallet.

\section{Primary Research}

This study uses two methods to gather data from primary research: a survey of people who currently don't have any e-wallet account, and interviews with e-wallet representatives. The survey data was targeted to be gathered from 400 respondents who currently don't have any e-wallet account. The survey aims to understand the untapped market standpoint and discover their view and expectation towards e-wallet services.

The data was collected from the participants' responses with a Google Form questionnaire spread using a "snowball sampling method", where one participant helps spread it to other people. The questionnaire is divided into four sections, the first section included background information about the respondents and their profile information, such as demographic questions, and monthly spending. The second section charted the respondents' perception towards information limitation about e-wallet and highlighted key reasons why respondents are reluctant to have an e-wallet account and use e-wallet for daily transactions. The third section included questions about the reliance on cash transactions and figured out participants' perception of e-wallet security and reliability. Finally, the last section covers the key motivation that drives participants to use e-wallets.

Most of the respondents were 46-55 years old. This aligns with a study from Ipsos Indonesia (2020), which stated that 68 percent of digital wallet users are categorized as millennials (people born from 1981 to 1996). Respondents mostly hold a bachelor's degree (38.7 percent), followed by elementary to high school graduates (37.8 percent). Further, the monthly expenses of the respondents are mostly Rp1,200,001-Rp6,000,000, which according to the World Bank categorized as middle class. Up to 64 percent of respondents lived in West Java.

This study also discovered insights from representatives of four prominent e-wallet providers in Indonesia. The interview aims to understand the challenge faced by the company to penetrate more widely, validate the hypotheses, and leverage their insights to develop the strategy.

The interviews followed a semi-structured format and lasted from 30 to 45 minutes. The interviews were recorded and transcribed, and the data were then grouped based on key highlights mentioned by the interviewee. The data analysis followed the qualitative clustering method, that is, grouping and then conceptualizing excerpts that have similar patterns or characteristics (Miles and Huberman, 1994). The purpose of the analysis was to identify key challenges faced by e-wallet providers and validate the challenges of digital payment adoption in Indonesia.

\section{Challenges in E-Wallet Penetration}

a. Making e-wallet usage ubiquitous across layers and locations

E-wallet technology is often described as a means to improve financial inclusion. The leading e-wallets target primarily affluent, urban populations with compatible devices to run the application. However, technology development in e-wallet does not necessarily affect the e-wallet penetration, many other underlying factors can significantly affect the penetration, one of them being banked people. A study from the Boston Consulting Group or BCG (2020) found that in Indonesia, 57 percent of its banked respondents 


\section{International Journal of Current Science Research and Review}

ISSN: 2581-8341

Volume 05 Issue 02 February 2022

DOI: 10.47191/ijcsrr/V5-i2-03, Impact Factor: 5.825

IJCSRR@ 2022

www.ijjcsrr.org

use e-wallets, compared with 26 percent of underbanked Indonesians and only 14 percent of the unbanked. It can be seen that bankability has an impact in increasing people's intention to regularly use e-wallet since users need to integrate their e-wallet account with the bank account

Further, the e-wallet penetration is still centered mainly in the Greater Jakarta area, location and accessibility still have significant disparity between Java and outside Java. Device requirements become a critical factor to determine penetration success in one area. Take a look in Africa, where digital literacy and device familiarity have created a significant mobile payment success, which directly outpaced the traditional financial services. The evolution to next-generation mobile payments is being driven by greater smartphone adoption throughout the continent.

E-wallets must be much more widely used by consumers at all income levels and far more ubiquitous for the industry to significantly scale up and obtain financial inclusion in the country. That is why LinkAja, which serves customers under State-Owned Enterprises (SOEs), stated that the company has the responsibility to improve the accessibility of e-wallet outside urban city areas and reach the unbanked population. The penetration must also be supported with education towards e-wallet products and their functionalities, especially in remote areas with less access to information.

b. Upgrading customer loyalty and value addition

Customer loyalty with e-wallets remains relatively low in Indonesia, and customers tend to jump from one app to another based on the discounts or cashback they provide. Interviewees mentioned that if the company stops giving rewards, there is a huge possibility that people will move to other e-wallets, so it's hard to find a balance between retaining customers and sustaining the business.

This also aligns with the findings from the BCG (2020) study in Southeast Asia. They found that in Indonesia, promotional discounts and cashback ranked as the most important reason for using an e-wallet. However, their analysis also discovered that e-wallet providers might reduce customer reliance on discounts. Even if the e-wallet providers did not provide promotions or discounts, 60 percent of urban customers in the region indicated that they would continue to use their e-wallets.

\section{c. Increasing bank and merchant integration}

Interviewees agree that integration with banks is one important factor to improve acceptance and reliability. Breaking the bank will be the norm across the industry soon. DBS Bank (2020) projects e-wallet transaction value to rise fivefold to US $\$ 50$ billion by 2025 when many providers will face a severe cash burn to acquire more users.

SeaMoney can be a great example of lessons learned. Due to extensive advertising, the digital payments service loses approximately US\$10 per user on US\$3 income. Meanwhile, OVO is said to merge with Dana to strengthen its top spot, while LinkAja has joined Gojek's ecosystem. Both OVO and GoPay are vying for a larger share of the market, especially after GoPay merged with Tokopedia, the competition is getting more intense.

Besides banks, integration with merchants is also important to increase the value and acceptance in rural cities. Operating an ewallet business is very lucrative. However, key players find it challenging to acquire more merchants since the costs are relatively high, while customer loyalty is still low.

\section{Cultural and Language Barriers}

Most respondents agree that there is a language barrier in e-wallet information. Respondents from urban provinces like Jakarta find it easier to get insights about e-wallet and figure out which providers can offer them their needs. However, in provinces like West Nusa Tenggara, East Kalimantan, even in a more rural region in West Java, respondents still find difficulties in accessing information about e-wallet. This shows a significant disparity between provinces.

With many e-wallet options offering diverse features and benefits, respondents wish that they can understand what sets one e-wallet provider apart from the other. Therefore, e-wallet providers must be able to identify needs and build holistic solutions through product offerings and key benefits.

The interview also revealed that technology enablement does not necessarily improve financial literacy enablement. Many other variables affect the level of e-wallet penetration that needs further analysis. To increase e-wallet penetration, there should be the 


\section{International Journal of Current Science Research and Review}

ISSN: 2581-8341

Volume 05 Issue 02 February 2022

DOI: 10.47191/ijcsrr/V5-i2-03, Impact Factor: 5.825

IJCSRR@ 2022

www.ijjcsrr.org

driving forces to push e-wallet use, and it comes mainly from e-wallet education. The one platform that can be the enabler is T-Cash which was established by Telkomsel in 2010. T-Cash can be used for various transactions such as shopping, bill payments, paying merchants, credit top-up, and transfer cash. Since T-Cash is the pioneer of e-wallet in the country, the switching effort can be minimized.

Further, the most significant knowledge gap comes from people in old age, they find it hard to look for information since there is less channel for them to access information about e-wallet, as well as a lack of technological literacy. Therefore, many e-wallet providers will be less likely to target old people to use their products and focus more on introducing e-wallet services to the productive ages.

\section{Reliance Towards Cash Payments}

The respondents are more likely to use non-cash payment methods if it is more convenient as compared to using cash. The majority of respondents agree that they are still comfortable with cash payments and feel that it is much easier rather than using an e-wallet for payment. The responses were nearly consistent through every question, agreeing that cash payment for online shopping and bank transfers are more reliable.

Security is also a key concern for participants, with 36 percent strongly agreeing that there could be a data leakage when they transact using the e-wallet. This implies that to improve perception towards security, both government and e-wallet providers must be able to guarantee safe and secure transactions, especially to protect the users' data from any kind of breach.

People's trust level towards e-wallet is one of the reasons why they still rely on cash payment, especially after data leakage cases from e-commerce in Indonesia. If such cases continue to rise, then people's trust towards payment systems like e-wallet will significantly deteriorate. Safety and reliability now come as a priority in product development, ensuring a secure, yet accessible compared to a conventional bank. The National Cyber and Encryption Agency (BSSN) revealed that Indonesia had recorded more than 88 million cyber-attacks during the first quarter of 2020, and more unreported cases. On the other hand, the APJII survey found that 57.8 percent of respondents claimed their data on the internet was secure and 66.4 percent said that the virus has never infected their devices.

\section{Distribution Networks}

Interviewees mentioned that the market opportunity for e-wallet in Indonesia remains big. Different target markets among e-wallet providers can be a benefit for them since each company can't satisfy all types of customers. For LinkAja, the market share will potentially be very high since it is fully supported by the government to improve accessibility in rural regions in Indonesia, and is predicted to be the longest to survive in the e-wallet business.

For private e-wallet providers like OVO and Dana, different market segments can be a real problem since both companies need a more established ecosystem like GoPay and ShopeePay. Providers with a strong app ecosystem have experienced rapid growth in recent years, and have gradually added additional features to their features and offerings. For example, GoPay is seen to have an advantage in the market, especially after its merger with Tokopedia to become Goto, offering an integrated ecosystem of services, and benefiting from greater acceptance than competitors.

\section{Government Authority}

Government has a significant role in providing supportive policies that can help enhance the whole e-wallet ecosystem. But before considering the policies, the government must fully control the transaction data of its citizens, so that the government can understand the consumption and people activities. The government is also responsible to avoid chances of corruption and fully control all transaction access in the country.

Governments and regulatory bodies are responsible for promoting the digitization of financial transactions. As a key regulator in the industry, BI has promoted the use of chip-based stored-value cards as an alternative to cash, and the government has built a national payment gateway to provide interconnection and interoperability of domestic retail payment instruments. 


\section{International Journal of Current Science Research and Review}

ISSN: 2581-8341

Volume 05 Issue 02 February 2022

DOI: 10.47191/ijcsrr/V5-i2-03, Impact Factor: 5.825

IJCSRR@ 2022

www.ijjesrr.org

\section{Internet Infrastructure}

While all major regions in Indonesia face slow internet connections, some other regions have no internet. So, it is surprising how badly Indonesia is ranked among other Southeast Asia countries. Yet, it is still fate that most Indonesian people should accept.

Geographical conditions in Indonesia are dominated by mountains and rivers, and this is one of the strong factors behind the slow connectivity. This geographical condition often led to failure in building communication infrastructure. This implies that to better penetrate e-wallet more widely, then the internet connection and infrastructure should be addressed first. To successfully carry out the digital transformation, it needs a strong internet connection even in remote areas.

\section{Motivation to Use E-Wallet}

Most respondents agree that using an e-wallet for transactions can be more expensive, since users must top-up a balance, and must pay an admin fee for each top-up. Some respondents also think that e-wallet products can make them more consumptive, thus making them spend more money. Again, education towards e-wallet features, benefit, as well as risk is highly important and must be prioritized in the literacy agenda.

Social influence has positive impacts on the customers' behaviors on mobile-wallet enforcement (Megadewandanu et al., 2017). The survey has proven that the key intention to use e-wallet is also driven by social influence. The majority of respondents agree that if their family and friends use an e-wallet, along with many stores or merchants that allow payment using an e-wallet, then they will be motivated to use the e-wallet.

\section{ADVICE FOR POLICYMAKERS}

To promote financial inclusion, regulatory bodies must encourage the development of e-wallet infrastructure. Thailand, for example, has launched PromptPay, a real-time retail payment system that enables free, immediate money transactions with high levels of security. Such moves take several days in most parts of the region. Several Southeast Asian nations, such as Singapore and Thailand, have followed China's lead and are well on their way to implementing standardized QR codes.

The discrepancy in the use of conventional financial products is due to infrastructure that is at varying stages of development. In Indonesia, credit card usage is still relatively low, making the country's credit agencies lack information on low-income people's creditworthiness. Hence, several e-wallet providers initiated to create a pay later product, which allows users to delay payments or debts that can be repaid at a later date. Pay later has a similar business model with credit cards offered by the conventional banks, but more accessible especially for the underbanked people both in the urban and rural areas. From pay later, the government and regulators can monitor and control the credit information of its citizens, and utilize them to define the creditworthiness of each province.

Further, governments and regulators must also support the digitization of financial transactions. In terms of payment infrastructure, Indonesia still lags behind China, India, and other Southeast Asian countries, as Indonesia still has limited capacity to transfer funds directly to nonbanks. Infrastructure in Singapore and Thailand, however, is improving, with real-time retail payment systems already in place. In 2018, the Philippines launched InstaPay, a national retail payment system. In Indonesia, BI is encouraging people to use chip-based stored-value cards instead of cash, and the government has set up a national payment gateway to ensure that domestic retail payment instruments are interconnected and interoperable. 


\section{International Journal of Current Science Research and Review}

ISSN: 2581-8341

Volume 05 Issue 02 February 2022

DOI: 10.47191/ijcsrr/V5-i2-03, Impact Factor: 5.825

IJCSRR@ 2022

\section{E-WALLET: THE ENDGAME}

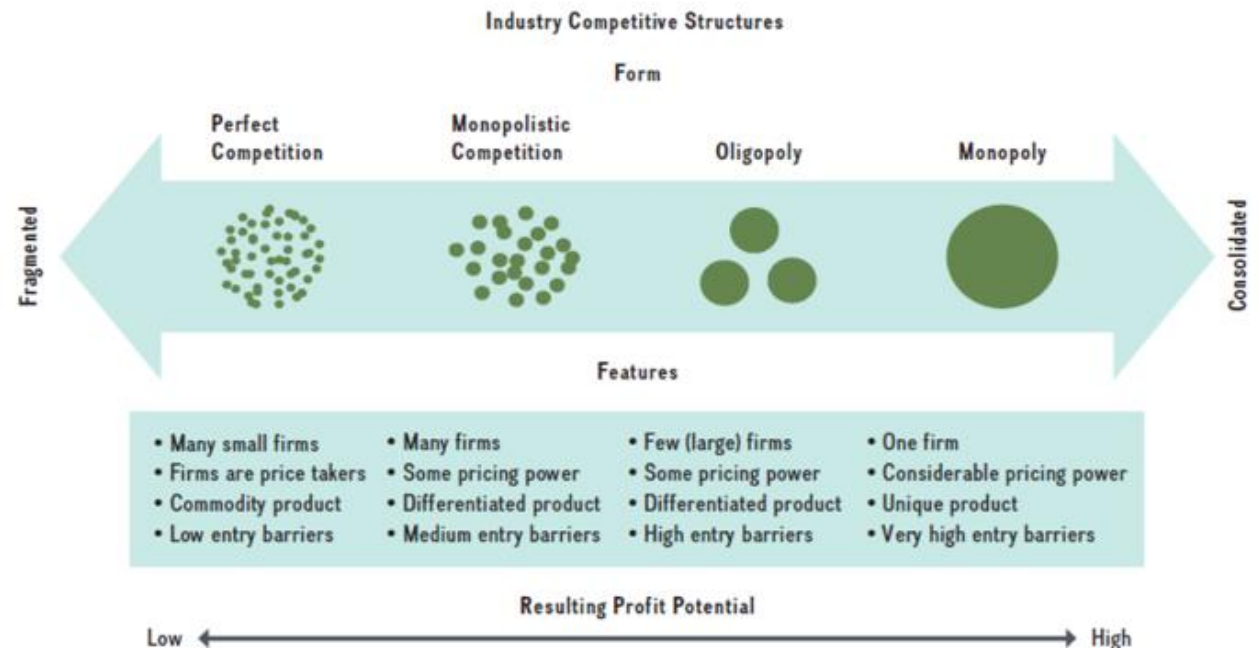

Figure 5. Continuum from fragmented to consolidate

Source: Rothaermel, F.T (2017)

As the field consolidates, this scenario is likely to alter. Many e-wallet providers are burning cash on incentives and charging no fees to acquire as many users as possible - an unsustainable business model. Several small e-wallet providers will very likely be driven out of business or acquired by larger, financially stronger competitors in the same archetype, or they will form strategic partnerships with commercial banks. The major regional companies, including Singapore-based ShopeePay, backed by SEA Group, and Indonesia-based digital payment provider GoPay which is supported by a solid ecosystem in Gojek, will likely thrive in the ewallet business.

\section{CONCLUSION}

Indonesia has made progress toward its objective to encourage the use of e-wallet payments. Despite its slower growth in terms of internet users compared to other Southeast Asian countries, the issues facing Indonesia's financial services are identified: weak formal institutions and legal structures; business with considerable influence in steering standards; a high unbanked population not familiar with financial services; low broadband penetration; limited and spotty internet access; lack of education and information services in the native language; and arbitrary filtering (Azali, 2016).

Additionally, the following key insights are concluded from this study for each subject.

\section{For e-wallet providers}

1. Technology enablement such as smartphone and internet penetration does not correlate with e-wallet penetration. Many underlying factors affect the penetration, such as key driving forces, infrastructure readiness, and people's perception of the safety and security of mobile transactions.

2. There is a significant knowledge gap in people's familiarity with e-wallet providers' product offerings since people still find it hard to find an e-wallet product that fits their needs. For some respondents, despite having no e-wallet accounts or even never using e-wallet as a means of payment, their willingness to learn further about e-wallet remains high and argued that education about e-wallet products and benefits is highly important, especially outside the Jakarta area where e-wallet usage is still low.

3. Since customers are highly driven by cashback and discounts, e-wallet providers must pay attention to their cash burns. Instead, try to focus more on providing value rather than continuously acquiring new customers through discount war. Through this approach, e-wallet providers can also have the opportunity to capture new demand from the untapped market by focusing on emphasizing benefits rather than providing discounts which could harm business sustainability in the long run. 


\section{International Journal of Current Science Research and Review}

ISSN: 2581-8341

Volume 05 Issue 02 February 2022

DOI: 10.47191/ijcsrr/V5-i2-03, Impact Factor: 5.825

IJCSRR@ 2022

www.ijjcsrr.org

4. The e-wallet industry relies heavily on regulations provided by regulatory bodies such as BI, and OJK. They provide a roadmap and guidelines that must be followed by e-wallet providers in Indonesia. In a stakeholder management context, regulatory bodies must be managed closely and provide information to maintain their support and discuss with them regularly to gather their feedback.

\section{For policymakers}

1. Encourage the development of e-wallet infrastructure by providing a real-time payment system that enables free, immediate money transactions with high levels of security, as well as implementing standardized QR codes to improve payment integration.

2. Continuously monitor and control the credit information of its citizens and utilize them to define the creditworthiness of each province using information gathered from pay later products provided in e-wallet.

3. Support the digitization of financial transactions, by continuously improving capacity to transfer funds directly to nonbanks.

This study concludes that the adoption of e-wallet requires committed leadership from regulatory bodies and an enthusiastic private sector adhered together by financial education and a culture of trust in the e-wallet system. Providing safe, and secure payment facilities is a key to building trust which will significantly contribute to financial inclusivity, especially in areas where internet and smartphone penetration are relatively high.

Each regulatory body must also coordinate to ensure regulation alignment, by getting involved in the BI master plan, supporting the digitization of financial transactions with the local authority, monitoring and controlling the credit information gathered from pay later products, and taking full control of the e-wallet industry to promote payment inclusivity.

\section{REFERENCES}

1. Aswicahyono, H., Hill, H. (2015) Is Indonesia Trapped in the Middle?. Working Paper, Department of International Economic Policy. Freiburg: University of Freiburg

2. Azali, K. (2016) Cashless in Indonesia: Gelling Mobile E-frictions?, Journal of Southeast Asian Economies Vol. 33, No. 3 (2016), pp. 364, $2339-5206$.

3. Chirlo, G (2018) The 6 Ways to Grow a Company, cited from: https://hbr.org/2018/06/the-6-waysto-grow-a-company. Downloaded on December 11, 2021

4. Dev, S.M., (2006) Financial Inclusion: Issues and Challenges, Economic and Political Weekly Vol. 41, 14 - 20.

5. Indonesia e-wallet transaction to reach $\$ 18.5$ billion in 2021 amid fierce competition, cited from: https://www.theasianbanker.com/updates-andarticles/big-tech-platforms-heat-upcompetition-in-indonesias-digitalpaymentslandscape. Downloaded on August 12, 2021

6. Indonesia Freedom on the Net 2020, cited from: https://freedomhouse.org/country/indonesia/freedom-net/2020. Downloaded on September 17, 2021

7. Indonesian internet users hit 196 million, still concentrated in Java: APJII survey, cited from: https://www.thejakartapost.com/news/2020/11/11/indonesian-internet-users-hit-196million-still-concentrated-in-javaapjiisurvey.html. Downloaded on August 06, 2021

8. Innovate Indonesia: Unlocking Growth Through Technological Transformation, cited from: https://www.adb.org/publications/innovateindonesia. Downloaded on September 5, 2021

9. Kreyer, N., Pousttchi, K., Turowski, K. (2003) Characteristics of Mobile Payment Procedures, ISMIS'02, Z. Maamar, W. Mansoor, and W.-J. van den Heuvel (eds.), Lyon 2002

10. Laporan Survei Internet APJII 2019-2020 (Q2), cited from: https://apjii.or.id/survei. Downloaded on August 19, 2021

11. Mallat, N., Tuunaien, V.K., (2008) Exploring Merchant Adoption of Mobile Payment Systems: An Empirical Study, eService Journal, Vol. 6, No. 2 (Winter 2008), 24 - 57.

12. Mobile Payments in Indonesia: Race to Big Data Domination, cited from: https://mdi.vc/whitepaper/detail/3/Mobile\%20Payments\%20In\%20Indonesia\%3A\%20Race\%20to\%20Big\%20Data\%20 Domination. Downloaded on September 24, 2021 


\section{International Journal of Current Science Research and Review}

ISSN: 2581-8341

Volume 05 Issue 02 February 2022

DOI: 10.47191/ijesrr/V5-i2-03, Impact Factor: 5.825

IJCSRR @ 2022

Www.ijesrr.org

13. Nair, V.P. (2016) Eschewing Cash: The Challenges of Cashless Transactions in the Philippines, Journal of Southeast Asian Economies Vol. 33, No. 3 (2016), pp. 364, 2339 - 5206.

14. National Park Service (2013) Using Scenarios to Explore Climate Change: A Handbook for Practitioners. National Park Service Climate Change Response Program. Fort Collins, Colorado. Payments in Indonesia: Understanding How to Enter Southeast Asia's Fastest Growing Digital Economy, cited from: https://www.xendit.co/en/payments-inindonesia/. Downloaded on August 14, 2021

15. Pisano, G.P. (2015) You Need an Innovation Strategy, cited from: https://hbr.org/2015/06/you-need-aninnovation-strategy. Downloaded on December 8, 2021

16. Porter, M.E., (1996) What is Strategy?, Harvard Business Review.

17. Raina, K. V. (2003). Overview of Mobile Payment: Technologies and Security. Electronic Payment Systems for Competitive Advantage in E-Commerce (pp.31)

18. Ranked in 92, why is the internet in Indonesia so slow?, cited from: https://aqi.co.id/en/news/duduki-ranking-92kenapa-internet-di-indonesia-lelet. Downloaded on August 05, 2021

19. Siapa Aplikasi E-wallet dengan Pengguna Terbanyak di Indonesia?, cited from: https://iprice.co.id/trend/insights/e-wallet-terbaik-di-indonesia/. Downloaded on September 15, 2021

20. Southeast Asian Consumers Are Driving a Digital Payment Revolution, cited from: https://www.bcg.com/publications/2020/southeast-asian-consumers-digital-payment-revolutions. Downloaded on September 20, 2021

21. Teo, E., Fraunholz, B., Unnithan, C. (2005) Inhibitors and Facilitators for Mobile Payment Adoption in Australia: A Preliminary Study, International Conference on Mobile Business, ICMB 2005, IEEE, Los Alamitos, Calif., pp. 663-666.

22. The 2021 McKinsey Global Payment Report, cited from: https://www.mckinsey.com/industries/financial-services/ourinsights/the-2021-mckinseyglobal-payments-report. Downloaded on October 15, 2021

23. The Changing Landscape of Digital Payments in Asia, cited from: https://www.dbs.id/id/corporate/research-andinsights/ business-insights/the-changinglandscape-of-e-wallet-players-in-asia. Downloaded on September 22, 2021

24. Top five non-banking e-wallets in Indonesia, cited from: https://techcollectivesea.com/2020/04/03/topfive-non-banking-ewallets-in-indonesia/. Downloaded on August 05, 2021

25. Vogwell, D. (2003). Stakeholder management. PMI® Global Congress 2003-EMEA, The Hague, South Holland, The Netherlands. Newtown Square, PA: Project Management Institute.

26. Widjaja, E.P.O. (2016) Non-Cash Payment Options in Malaysia, Journal of Southeast Asian Economies Vol 33, No. 3 (2016), $398-4$.

27. Winner Takes All in the Battle for E-wallet Supremacy, cited from: https://www.oliverwyman.com/content/dam/oliverwyman/v2/publications/2018/june/WinnerTakes-All-In-The-Battle-For-E-Wallet-Supremacy.pdf. Downloaded on August 22,2021

Cite this Article: Augi Ciptarianto, Yudo Anggoro (2022). E-Wallet Application Penetration for Financial Inclusion in Indonesia. International Journal of Current Science Research and Review, 5(2), 319-332 